$\begin{array}{ll} & \text { Etnográfica } \\ \text { etnográfica } & \text { Revista do Centro em Rede de Investigação em }\end{array}$

Antropologia

vol. $19(1) \mid 2015$

Vol. $19(1)$

\title{
Arte e etnografia cokwe: antes e depois de Marie- Louise Bastin
}

Cokwe art and ethnography: before and after Marie-Louise Bastin

\section{Nuno Porto}

\section{(2) OpenEdition}

\section{Journals}

\section{Edição electrónica}

URL: https://journals.openedition.org/etnografica/3941

DOI: 10.4000/etnografica.3941

ISSN: 2182-2891

\section{Editora}

Centro em Rede de Investigação em Antropologia

\section{Edição impressa}

Data de publição: 1 fevereiro 2015

Paginação: 139-168

ISSN: 0873-6561

\section{Refêrencia eletrónica}

Nuno Porto, «Arte e etnografia cokwe: antes e depois de Marie-Louise Bastin», Etnográfica [Online], vol. 19 (1) | 2015, posto online no dia 06 março 2015, consultado o 09 fevereiro 2022. URL: http:// journals.openedition.org/etnografica/3941 ; DOI: https://doi.org/10.4000/etnografica.3941

\section{(c) (1) (8)}

Etnográfica is licensed under a Creative Commons Attribution-NonCommercial 4.0 International License. 


\section{Arte e etnografia cokwe: antes e depois de Marie-Louise Bastin}

Nuno Porto

Este texto parte do recenseamento e debate sobre o contexto em que o trabalho empírico de Marie-Louise Bastin no Dundo (1956) e a publicação original de Art Décoratif Tshokwe (1961) ocorrem, e analisa as recorrências contemporâneas do contexto de produção de categorias de "arte africana" e o seu consumo como "arte nacional". O trabalho levado a cabo no Museu do Dundo desde 1936 permite inscrever a emergência da categoria de arte durante os anos 50 e 60 no contexto da promoção internacional da cultura material cokwe como "arte", em detrimento da sua classificação, até aí vigente, como "etnografia". Neste sentido, a promoção dos artefactos cokwe como "arte" está em relação com uma nova política de desenvolvimento do museu - que, entre outros fatores, motivara a cessação de funções de José Redinha como conservador (em 1959) - no quadro das transformações políticas na arena internacional. A análise deste processo, argumenta-se, revela-se útil a dois níveis: por um lado, para pensar relações entre o local e o global mediadas pela categoria de "arte"; por outro, na medida em que a categoria de "arte" constitui um fator de empoderamento de sujeitos ou populações, a análise de processos passados pode tornar-se um ponto de partida para compreender processos contemporâneos, tais como os que são analisados e debatidos a propósito da 1. ${ }^{a}$ Trienal de Luanda, como se propõe na segunda parte deste texto.

PALAVRAS-CHAVE: Angola, arte africana, arte contemporânea, etnografia, Trienal de Luanda.

Cokwe art and ethnography: before and after Marie-Louise Bastin Departing from Marie-Louise Bastin's research visit to the Dundo Museum in 1956 and the publication of both volumes of Cokwe Decorative Arts (1961), I analyze contemporary recurrences of the context of production of categories of "African art" and its consumption in Angola as "national art". The colonial context in which Cokwe material culture, classified as ethnography, become classified as art, enabled a transition which developed in relationship to a new policy of development of the Dundo Museum. The analysis of this process is critical to understand local and global relationships mediated by the category of African art and its colonial efficacy, as well as it is illuminating of present-day politics, expressed in art terms, in contemporary Angola.

KEYWORDS: Angola, African art, contemporary art, ethnography, Luanda Triennial.

PORTO, Nuno (nuno.porto@ubc.ca) - Museum of Anthropology, University of British Columbia, Canada; Centro em Rede de Investigação em Antropologia, Portugal. 


\section{CONTEXTOS DE ARTE COKWE}

\section{Tempo do colono: a internacionalização do trabalho do Museu do Dundo}

Um dos efeitos quase imediatos do trabalho de Marie-Louise Bastin consistiu no reconhecimento internacional da arte cokwe. ${ }^{2}$ Esse efeito não foi casuístico e inscreveu-se numa política de internacionalização do Museu do Dundo, correspondente a uma segunda fase de desenvolvimento que fora iniciada com a finalização do edifício construído para o albergar em 1946 e a contratação do biólogo Barros Machado para a sua direção no mesmo ano. Até este ano, o museu fora dirigido por José Redinha, que passa a responsável pela secção de Etnografia, tendo tido a seu cargo as primeiras recolhas, a instalação das coleções - primeiro, numa casa de habitação no Dundo e, depois, no novo edifício do museu -, a instalação de um "terreiro folclórico" e a construção de uma "aldeia nativa".

Barros Machado era um académico e, no projeto de instituição do Laboratório de Investigações Biológicas (LIB), prevê a constituição de uma rede internacional para colaborar nas investigações de campo. O LIB seria um "laboratório de campo" assessorado por uma rede internacional de cientistas que, em 1947, contava 133 "colaboradores" e 151 "correspondentes". ${ }^{3}$ É sob este propósito que, nesse mesmo ano, Barros Machado desenvolve uma missão a universidades, centros de investigação e museus na Europa e em África, na qual se sedimenta o Museu Real da África Central (o Museu de Tervuren), perto de Bruxelas, como uma metrópole científica do Museu do Dundo, quer para as investigações biológicas, quer para a etnografia.

Este programa de desenvolvimento do Museu do Dundo ocorre num momento crítico para a política colonial portuguesa (e, por conseguinte, para a Companhia de Diamantes de Angola, Diamang), que conduz à revisão constitucional de 1951, pela qual as colónias passam a ser chamadas "províncias ultramarinas". A convite do novel Ministério do Ultramar, Gilberto Freyre visita o Dundo e qualifica a política colonial da Diamang como "antilusitana",

I O presente texto é uma versão muito revista do texto apresentado em Luanda, em novembro de 2010, no âmbito do colóquio "Arte na Sociedade Cokwe e nas Comunidades Circunvizinhas", por ocasião do lançamento da edição em língua portuguesa de Arte Decorativa Cokwe, de Marie-Louise Bastin. Uma versão anterior fora apresentada na sessão "Continuities and ruptures in the study of African contexts: a place for the history of the present", organizada por Jorge Varanda e Todd Cleveland para o 7. ${ }^{\circ}$ Congresso Ibérico de Estudos Africanos, realizado em Lisboa em 2009. Gostaria de expressar os meus agradecimentos aos organizadores e participantes em ambos os eventos, bem como aos revisores anónimos de diferentes versões deste texto, cujos comentários, críticas e sugestões permitiram a atual versão.

2 O uso de diferentes formas de grafia para designação dos cokwe - cokwe, na grafia contemporânea, quioco e tshokwe na grafia colonial e tchokwé, segundo a Trienal de Luanda - pretende especificar diferentes posicionamentos de referência ao grupo, posicionamentos esses que não são neutros do ponto de vista do argumento desenvolvido.

3 Que passariam, em 1962, para 198 e 244, respetivamente. 
instaurando um "drama social" que suscita a contratação de José Osório de Oliveira como divulgador da "obra" da Diamang, dada a incapacidade, para o efeito, do conservador de Etnografia, José Redinha.

\section{Marie-Louise Bastin}

E assim, após a passagem pelo Museu do Dundo de Olga Boone (em 1948), Albert Maesen (em 1954) e Franz Olbrechts (em 1955), ${ }^{4}$ é a vez de o próprio J. O. Oliveira se deslocar a Paris e a Tervuren para - sob o patrocínio da Companhia - fazer o estudo comparativo da arte negra. Fora antecedido por Barros Machado, em missão biológica, que complementa as informações sobre o Museu do Dundo, aí prestadas por Redinha aquando da visita de Olbrechts ao Dundo. Na sequência da estadia do escritor J. O. Oliveira em Tervuren, é o próprio Olbrechts quem propõe a ida de Marie-Louise Bastin para o Dundo, ainda em 1955:

"Exm. ${ }^{\circ}$ Senhor Ernesto de Vilhena

Administrador-Delegado

Companhia de Diamantes de Angola,

Rua dos Fanqueiros, 12

LISBOA

Tervuren, Bélgica, 12 de Outubro de 1955

Senhor Administrador-Delegado,

$[\ldots]$

Discuti com o Sr. de Barros Machado e o Sr. Redinha os problemas que falta resolver no Museu do Dundo tanto do ponto de vista científico, artístico e museográfico e permito-me, com base no que me disseram, fazer-vos uma sugestão:

Creio que seria da maior importância para os nossos dois Institutos que uma pessoa ligada ao nosso Museu pudesse passar 5 ou 6 meses no Dundo para ajudar o Sr. Redinha a elaborar duma forma científica as questões importantes dos estilos e subestilos da arte Kioka (Ciokwe) e Lunda e para valorizar, de uma forma eficaz, as colecções que vós possuís.

Temos no Museu uma colaboradora, a Sr. ${ }^{a}$ M.L. Bastin, que após ter seguido durante vários anos os cursos do nosso melhor Instituto de Arte Decorativa, ocupa-se no Museu, desde 1948, de duas funções: no nosso Centro Internacional para o Estudo da Arte Africana, classifica e estuda os milhares de documentos iconográficos [...]; ela ocupa-se, ainda, da apresentação artística das nossas colecções e, se bem que nos seja penoso passar sem

4 Especialistas em assuntos africanos do Museu de Tervuren, nas áreas da Arqueologia, Etnografia e Arte, respetivamente. 
os seus serviços durante 6 meses, estaríamos dispostos, se V. o julgar útil, a emprestá-la durante esse período de tempo.

O Sr. Oliveira, aquando das duas visitas que nos fez, acompanhou o trabalho da Sr. ${ }^{a}$ Bastin e poderia dar-vos informações sobre isso.

A Sr. ${ }^{a}$ Bastin estaria disponível para se apresentar no Dundo a partir de 15 de Janeiro de 1956, ou mais cedo se V. Ex. ${ }^{a}$ o preferir.
$[\ldots]$
F. Olbrechts
Director"

Trata-se da primeira de uma série de 47 cartas trocadas entre Bruxelas, Lisboa e o Dundo a propósito desta visita, claramente do interesse da Administração da Diamang. Em resposta a Olbrechts, Ernesto de Vilhena acede de bom grado a este projeto, mas clarifica:

"4. [...] devemos explicar a V. Ex. ${ }^{\text {, }}$ que as nossas colecções se dirigem, especialmente, ao elemento indígena, ao qual, devido à existência da nossa indústria abrangendo um território assaz vasto, nos empenhamos em prestar uma assistência completa, mesmo sob o ponto de vista da sua vida tradicional. A este título, nós não podemos ignorar que o gosto indígena faz apelo a uma preferência marcada pelo número, e que desta forma ele é levado a admirar um conjunto mais rico pela quantidade do que pela escolha da melhor qualidade. Por este motivo, nós consideramos que a apresentação dos objectos tal como eles são expostos no Dundo realiza a finalidade que o museu se propõe atingir. Com efeito, enquanto que no caso dos conjuntos europeus é necessário mostrar um número de peças limitado e muito escolhido, devendo a atenção dos visitantes ser orientada, uma vez que ela está fortemente ocupada pelos milhares de preocupações próprias da vida moderna, no Dundo, não existindo estas últimas condições no elemento autóctone, foi-nos necessário adoptar, de preferência, um sistema que melhor se adequasse à sua natureza.

5. Esta modalidade, no entanto, não constitui um inconveniente para o conhecedor ou o etnógrafo, pois o nosso museu, que não o é no sentido formal da palavra, admite, sem outras formalidades, que os objectos possam ser deslocados para a Sala de Estudos, quando tal for necessário, de forma a permitir uma análise mais minuciosa, e, eventualmente, o seu agrupamento segundo certas características, para fins de comparação ou outros. Não queremos dizer que a apresentação de certas peças não seja susceptível de melhoramento, mesmo considerando o critério já exposto; mas não naquilo que diz respeito ao conjunto tal como ele se apresenta nas suas linhas gerais, 
uma vez que ele corresponde, como já o explicámos, ao gosto dos elementos indígenas, entre os quais se encontra um número assaz elevado de doadores, perante os quais não seria conveniente relegar os objectos a um plano secundário.

6. A acção da Sr. ${ }^{a}$ Bastin poderia também mostrar-se especialmente favorável na escolha de peças para fotografar, de acordo com a finalidade mencionada na nossa carta de 25 de Novembro, dirigida ao director do Centro Internacional para o Estudo da Arte Africana. Agradecemos que ela possa indicar aos nossos serviços fotográficos locais, a sua escolha, em como, na sua opinião, as fotografias devem ser feitas. Bem entendido, os nossos serviços do museu terão todo o prazer em dar a conhecer todas as outras actividades a seu cargo, como, por exemplo, a recepção de artistas e artesãos, na aldeia do museu. Da mesma forma serão facilitadas as deslocações às aldeias mais interessantes, do ponto de vista artístico ou etnográfico, que ela deseje visitar.

7. Pensamos também, Sr. Director, que a estadia da Sr. ${ }^{a}$ Bastin poderá revestir-se de um grande interesse no capítulo da classificação das peças de escultura, seguindo o Vosso próprio método e aplicando, neste interessante e importante domínio, os conhecimentos adquiridos junto de V. Ex. ${ }^{\mathrm{a}}$, em Tervuren.

8. Quanto ao estudo, em geral, das colecções, no sentido amplo do termo, nós aguardamos a visita ao Dundo do Dr. Hermann Baumann, no seguimento da estadia que ele aqui efectuou durante os meses de Agosto e Setembro de 1954. O objectivo é o de permitir-lhe completar a sua obra Lunda, publicada em 1935 e que diz respeito aos resultados da investigação efectuada em 1931 quase exclusivamente na parte central e meridional do distrito. O material recolhido no Museu permitir-lhe-á, com efeito, atingir este objectivo."6

Como o administrador-delegado deixa claro, a proposta de Tervuren é aliciante para ambas as partes; isto é, a Diamang poderia passar bem sem ela, mas só tem a ganhar com a sua realização. Não obstante, importa deixar claro que o interesse é mútuo: por um lado, o museu não o é "no sentido formal da palavra", pois os seus objetivos passam pela relação com a população nativa; esta - que inclui muitos doadores - prefere o número à seleção de peças, não convindo, em consequência, alterar a exposição; por outro lado, quanto ao estudo das coleções, Hermann Baumann, a maior autoridade científica sobre a Lunda, está já em campo. Mas sim, a uniformização na classificação da escultura pelo método de Tervuren, a escolha de uma seleção de peças e a instrução do

6 Arquivo documental da Diamang, Documentação Cultural Diversa, Vilhena-Olbrechts, 1955, carta 2. 
fotógrafo na fotografia de artefactos - são três valores acrescentados não desprezíveis. A proposta é, pois, aceite. Entretanto, informa-se o Dundo, Luanda, a delegação em Bruxelas. Retifica-se o programa de trabalho de Mlle. Bastin. Dez cartas e quatro meses depois, com data de 2 de abril de 1956, Ernesto de Vilhena envia a Tervuren alguns detalhes de última hora, entre os quais:

“4. Dado que esta estadia se efectua, na sua maior parte, durante a estação seca, devo aconselhá-la a levar alguma roupa de lã - camisolas, sweaters, e um bom casaco, além do impermeável contra as chuvas de Abril e princípio de Maio. Ser-lhe-ia também útil munir-se de um ou dois vestidos de cerimónia, pois penso que ela gostaria de assistir às festas da Casa de Pessoal, onde se realizam de vez em quando serões dançantes, na presença do Director-Geral e outros membros da Direcção local e suas famílias". ${ }^{7}$

Entretanto, escrevia novamente para o Dundo, ao cuidado da Direção-Geral na Lunda:

“14/4/56 - Vilhena - J. Tavares Paulo, Director-Geral da CDA na Lunda Exm. ${ }^{\circ}$ Senhor,

1. Como cremos ser do conhecimento de V. Ex. ${ }^{a}$, por efeito de visitas efectuadas ao Museu do Dundo e às explorações em geral, por pessoas de nomeada nos círculos artísticos e da investigação científica da Bélgica, entre os quais o Prof. Olbrechts, director do Museu de Tervuren, tem este Museu, em especial, procurado estreitar relações connosco, ao que vimos correspondendo na medida do razoável, isto é, não dando, a tal classe de relações um desenvolvimento incompatível com os nossos recursos e possibilidades. Dentro do espírito de cooperação assim criado, e dando seguimento a uma proposta daquele professor, concordámos em que um seu colaborador, Mlle. Marie-Louise Bastin, do "Centre International pour l'Étude de l'Art Africain”, organismo anexo à referida instituição, realizaria um estágio no Museu do Dundo, para estudar as nossas colecções etnográficas e conhecer o ambiente sui generis que incutimos a esta nossa iniciativa.

2. Pela cópia, que juntamos, da carta n. ${ }^{\circ} 356 / 55$, de 17 de Dezembro último, para o mesmo Dr. Olbrechts, ficará V. Ex. ${ }^{a}$ elucidado sobre as finalidades desse estágio, e qual o campo de acção de Mlle. Bastin. Como V. Ex. ${ }^{a}$ perceberá pela leitura da referida carta, o Dr. Olbrechts tinha a ideia de que a exposição dos objectos do nosso Museu ganharia em ser alterada, pela supressão dos de menor valor artístico e pela apresentação dos melhores

7 Arquivo documental da Diamang, Documentação Cultural Diversa, Vilhena-Olbrechts, 1956, carta 12 . 
em moldes decorativos diferentes, mais de acordo com os ensinamentos da moderna museografia.

$[\ldots]$

5. Bem entendido, Mlle. Bastin é hóspede da Companhia, durante o tempo que aí se demorar. Para despesas de bolso poderão ser-lhe abonadas as importâncias que a V. Ex. ${ }^{a}$ parecerem razoáveis. Vai munida de bilhete de ida e volta.

6. Sobre o estágio a que esta carta se refere voltaremos em breve a escrever a V.Ex. ${ }^{\text {"⿻ } 8}$

A receção em Lisboa é efetuada pelo casal Osório de Oliveira e, após uma semana de visita a algumas cidades do país e aos museus de Lisboa, M.-L. Bastin faz uma conferência na sede da empresa, antes de embarcar, nessa mesma tarde, para Léopoldville. ${ }^{9}$ Daqui seguirá de carro para o Dundo. Da sua chegada é informada a sede, em Lisboa, por telegrama. Durante a viagem fora acompanhada pelo casal Santos David. Contrariamente ao que a Administração sugerira, ficará no Dundo seis meses. Cinco anos mais tarde publicará o seu texto, como o número 55 das Publicações Culturais da Companhia de Diamantes de Angola.

\section{A arte decorativa dos cokwe}

No trabalho que desenvolve no Dundo entre 27 de abril e 4 de outubro de 1956, M.-L. Bastin é coadjuvada pelo “auxiliar indígena” Muacefo Elias, responsável pela Sala de História e equipamento do Folclore. Segundo os registos de maio desse ano:

"Manteve-se durante o mês como informador de Mademoiselle Bastin. Muacefo, descendente do Soba Sanjime, quioco, revelou-se um bom auxiliar de Mademoiselle Bastin, por entender um pouco de francês, português e escrever em língua indígena com relativa facilidade os nomes dos objectos e a sua utilização." 10

A investigadora, segundo o Diretor-Geral na Lunda, considera que "a grande quantidade de objetos expostos prejudica a apreciação das peças de maior valor, que se perdem no conjunto". ${ }^{11}$ No decurso de seu trabalho, a Muacefo Elias virá juntar-se Ditenda, outra autoridade tradicional, desta vez de origem Lunda. "Como fala e escreve razoavelmente o francês, foi empregue

8 Arquivo documental da Diamang, Documentação Cultural Diversa, Sede-Dundo, 1956, carta 21.

9 Atualmente Kinshasa.

10 Arquivo documental da Diamang, Museu do Dundo, Relatórios Mensais, maio de 1956, p. 2.

11 Arquivo documental da Diamang, Museu do Dundo, Relatórios Mensais, maio de 1956, p. 2, comentário extratexto. 
como intérprete dos dialectos 'lunda' e "quioco'." 12 Em julho, acresce a esta elite de "informantes" o escultor Chamua Cariango, artista da "aldeia" do Museu. ${ }^{13}$ A este núcleo central de intérpretes da cultura e arte cokwe viriam a associar-se, caso a caso, inúmeros outros especialistas em saberes e saberes-fazer tradicionais, que contribuirão para a execução de uma etnografia extremamente detalhada sobre as artes - qualificadas como "decorativas" - cokwe. Os dois volumes em que será publicada em 1961, na série editada pelo Museu do Dundo, constituem - como o administrador-delegado da Companhia faz notar no relatório aos acionistas desse ano - a "obra de referência sobre a arte da África Central". ${ }^{14}$

Podem distinguir-se três elementos que fazem dos dois volumes da publicação da autoria de M.-L. Bastin um texto de referência obrigatória sobre as artes cokwe: em primeiro lugar, o trabalho resulta do cruzamento aturado de informação histórica publicada até então sobre os cokwe e suas relações com os europeus, e do trabalho etnográfico de recolha de informação junto dos agentes locais, produtores e utilizadores dos artefactos em análise. Em segundo lugar, trata-se de uma etnografia exaustiva, pela qual todo o tipo de padrões formais entendidos como "artes decorativas" são escrutinados nos mais diversos suportes físicos, desde suportes naturais (e.g. nas pinturas de areia) a artefactos utilitários ou cerimoniais e, mesmo, o corpo humano. Por este meio, a autora revela uma linguagem dos diferentes elementos formais constantes na cultura material cokwe que - tendo por recurso conceptual o entendimento cokwe do universo natural e social - torna estes acessíveis na descrição dos objetos e padrões formais. Finalmente, o livro implica um processo técnico de comunicação em que texto, gravura e fotografia são conceptualmente interdependentes, de que resulta uma etnografia visual extremamente precisa, que fornece ao leitor a tradução cultural de objetos aparentemente exóticos. Não obstante, nem a noção de "arte" nem a noção de "arte decorativa" são objeto de abordagem teórica explícita, pelo que são constituídas ao longo do livro (texto e imagens) como signos naturais dos cokwe e da sua tradição cultural, por sua vez, em extinção.

Pode classificar-se como uma metodologia de análise de cultura material o trabalho seguido: segundo a autora, o trabalho parte de 400 objetos do museu explicados pelos seus informantes, separados em fornecedores de "informação etnográfica" - utentes dos artefactos, em especial, de adivinhação e "informação técnica" - entendida num sentido lato que compreende os nomes vernaculares da madeira utilizada na escultura, por exemplo, e os modos e técnicas de produção dos diferentes objetos, pinturas ou tatuagens. Sem o recurso à fotografia de Agostiniano de Oliveira, "cujo excelente trabalho artístico 
ornamenta este livro" (Bastin 1961: 20), a interpretação da autora sobre as decorações dos diferentes artefactos e sua remissão para o corpo humano seria improvavelmente conseguida. De facto, o exercício central do texto consiste em relevar a constância de figuras geométricas em diferentes suportes, proporcionando a designação vernacular de cada uma delas, bem como o seu significado para os cokwe, no que não pode deixar de se considerar um exercício da etnografia como "modalidade investigativa de vigilância" (segundo a terminologia de Cohn 1996), na medida em que fornece o código de uma linguagem articulada na decoração de artefactos e do corpo. ${ }^{15}$ Trata-se, neste sentido, de ultrapassar as limitações de Redinha ou Osório de Oliveira e respetivas formulações - ainda que distintas entre si -, norteadas pela questão estética, com o propósito de elucidar o caráter racional, prescritivo e lógico - de um ponto de vista cokwe - quanto à utilização em determinados objetos, circunstâncias, sujeitos e ações, de marcas gráficas específicas.

Necessariamente, este tipo de exercício opera por fragmentação: isto é, dado que o que está em análise é a recorrência de determinada forma gráfica em suportes diferenciados - diferenciados na sua natureza, utilização, durabilidade ou dimensão -, a autonomização ideográfica dessas formas - por gravura ou fotografia - tende a produzir um código gráfico legível como cultura cokwe, indiscriminadamente identificável em objetos que incluem, enquanto tais, sujeitos humanos. Este exercício de objetificação é particularmente visível na documentação referente às tatuagens, pinturas corporais e penteados, que se constituem em objetos discretos da estética cokwe, mediante a excisão visualmente produzida na ideografia, seja ela um fragmento corporal ou um fragmento de uma situação. O resultado do exercício consiste na abstração de um código transversal a objetos e sujeitos.

No entanto, nem todas as manifestações plásticas são equivalentes entre si, quer em termos da sua relevância para o grupo social, quer enquanto objetos estéticos. M.-L. Bastin, secundando as impressões de Redinha quanto ao caráter recente da pintura e ao amadorismo da prática, elege a escultura em madeira como a principal arte cokwe, por três razões principais: é uma arte honorífica, distinguindo os seus praticantes dada a responsabilidade que detêm sobre o exercício de representação de outrem, designadamente um chefe; é tradicional e, portanto, suscetível de recuar ao período pré-colonial; e é especializada, potenciando a acuidade técnica e estilística. Nas palavras da autora, "Executadas por um mestre, estas esculturas tornam-se verdadeiras obras de arte" (Bastin 1961: 58). Este caráter de obra de arte é atestado por um elevado grau de estilização, decorrente de uma prática transmitida dentro de determinadas famílias ao longo de gerações, trabalhando para clientelas politicamente 
relevantes - os "grandes chefes" (1961: 58). A intenção naturalista - "se o escultor respeitar os cânones tradicionais, procurará aumentar o encanto realista e, por esse meio, a eficácia de uma máscara, tomando por modelo uma mulher reconhecida pela sua beleza e atributos" (1961: 58) - está intimamente associada à relevância política da arte cokwe. Assim,

"Nalgumas obras de arte de estilo tshokwe, provenientes das antigas cortes de chefes, particularmente nas esculturas mais tardias, constata-se uma tendência ao espírito barroco: procura de expressividade nos rostos e trabalho muito elaborado dos detalhes do corpo que, apesar da sua estrutura assaz sumária, chega, por vezes, a sugerir movimento" (Bastin 1961: 58-59).

A afirmação de um "estilo tshokwe" constitui uma das conclusões centrais do seu trabalho, afirmação esta que é sustentada por dois elementos recorrentes na história da emergência das "artes negras", e dos diferentes estilos nelas referenciáveis. Trata-se de um argumento circular: por ser estilizada, a escultura é praticada por especialistas; os saberes destes especialistas são adquiridos no interior do grupo familiar, sendo saberes tradicionais e antigos; tem por consumidores preferenciais os grandes chefes e a sua corte; este consumo honorífico conduziu a uma elevada mestria artística e, em consequência, ao desenvolvimento de um estilo particular.

É um movimento discursivo deste tipo que Fabian (1998) identifica na emergência da conceptualização da cultura material kuba como arte, na viragem do século, e que é, por sua vez, confirmado por Keim (1998) relativamente à arte mangbetu. Isto é, quando a atribuição de valor político a um artefacto se processa, ele cessa de ser entendido como curiosidade e entra na categoria do objeto de arte. Na época, este entendimento da cultura material conduziu a uma "partilha" da arte africana por parte dos colecionadores, cujos interlocutores privilegiados são sujeitos politicamente proeminentes - veja-se a relação entretecida entre Emil Torday e Kot A Pe, chefe dos kuba (cf. Mack 1994). Em meados dos anos 60, na configuração adversa ao colonialismo português, as consequências na identificação de um estilo artístico são outras. Aqui, a escultura tshokwe adquire o estatuto de comprovativo material da profundidade histórica do grupo, bem como de uma correlativa complexidade da organização social, sobretudo em termos políticos. Ao cânone estilístico corresponde um cânone social que só pode ser (contemporaneamente) localizado no passado. Daqui resulta que, tal como os restantes objetos do Museu do Dundo, a arte tshokwe é pretérita e, mercê do processo colonial, terminada. Enquanto tal, remete para um tempo em que a organização política dos tshokwe era complexa. Fora da produção contemporânea, as esculturas de arte tshokwe são, por isso, raras e, portanto, valiosas. A consagração do estilo faz-se acompanhar da emergência de um nicho de "mercado" da arte negra 
- a escultura tshokwe. Nele, o lugar do Museu do Dundo é um lugar central, pelo que a até então posição subalterna em termos etnográficos é substituída por uma posição central em termos de arte tshokwe. Eis, em suma, em que consiste, do ponto de vista da administração, a mais-valia a retirar do estágio de M.-L. Bastin no Dundo.

Entretanto, entre o estágio e a publicação desta "obra de referência", Redinha publica os relatos da sua campanha ao Alto Tchiboco (1953a, 1955) e um novo álbum sobre Máscaras de Madeira da Lunda e Alto Zambeze (1956), estabelecendo alguma continuidade de publicações no campo etnográfico que virá a ser prosseguida, após a saída do conservador, por Mário Fontinha e Acácio Videira, adjuntos do Museu, sobre as Cabaças Gravadas da Lunda (1963), e pelo ex-chefe do Posto Administrativo do Cambulo, entretanto etnógrafo, e posteriormente diretor do Museu de Luanda, Mesquitela Lima, sobre os "akixi” da Lunda (1967). Após o estágio no Dundo, M.-L. Bastin conduz uma investigação extensiva comparando peças de arte tshokwe nos museus e coleções privadas da Europa, que conduzirá ao seu trabalho de doutoramento, apresentado em Bruxelas em 1973. Nele, estabelece o caráter definitivo da deslocação colonial do estilo que identificara:

"Se a arte tshokwe, como tantas outras desaparecidas, nos deu já tudo o que foi capaz de produzir de melhor, a sua contribuição, não sendo considerável em termos de número ou de volume, é de uma qualidade mais do que suficiente e duma originalidade suficientemente potente para constituir um enriquecimento real do nosso património artístico" (Bastin 1973: 289).

Em 1982, o apuramento do estilo da escultura tshokwe é proporcionado por um espetro comparativo bastante mais alargado, que lhe permite contrariar a tese de acordo com a qual a arte tshokwe seria "meramente tribal". ${ }^{16}$ Para além dos exemplares analisados no Museu do Dundo e no Museu de Tervuren, o texto inclui estudos de peças do Museum für Völkerkunde (Berlim), do Museu Nacional de Etnologia (Lisboa), do Museu de Antropologia da Universidade do Porto, do Museu e Laboratório Antropológico da Universidade de Coimbra, da Casa Museu Teixeira Lopes (Vila Nova de Gaia), da Pace Gallery (Nova Iorque), bem como das coleções privadas de Lance Entwistle, Jeff e René Van der Straete, Jean-Claude Bellier e dos Ginzberg. Na conclusão do texto, explica:

“Estes escultores 'contemporâneos' detêm, por vezes, capacidades técnicas invulgares. O facto da sua produção ser geralmente medíocre, deve-se, provavelmente, ao facto de terem sido capturados entre duas civilizações. 
Por um lado, não podem apoiar-se nos valores tradicionais. Por outro, é-lhes difícil assimilar o que a Europa tem para oferecer. Parece que todos os Artistas africanos enfrentam este mesmo problema” (Bastin 1982: 255).

Os 20 anos que separam a fundamentação inicial da proposta e a sua enunciação como facto estabelecido demonstram uma continuidade contrária ao processo histórico em curso, que parece surgir como uma irrupção pela concessão adentro. Com efeito, neste mesmo ano de celebração da edição do n. ${ }^{\circ} 55$ da coleção Publicações Culturais (Bastin 1961), reporta-se aos acionistas:

"Actos de terrorismo em Angola

Os acontecimentos desenrolados, desde o começo deste ano, em Luanda e no norte da Província, são de molde, pela sua origem e pela gravidade e características [de] que se revestem, a suscitarem profunda reflexão.

Sem pretendermos remontar às doutrinas de anticolonialismo, postas a correr, como rescaldo de ordem social e política nascid[a] da última grande guerra, em que teriam de filiar-se a causa primária da perturbação que, de modo geral, se está verificando em toda a África e as apreensões que, por esse motivo, justificadamente surgem sobre os perigos que ameaçam a paz no mundo, a verdade é que não pode deixar de atribuir-se ao facto de a generalidade das grandes potências coloniais se estarem demitindo de si próprias, sob o influxo daquelas doutrinas, sucessiva e precipitadamente, da soberania nos seus domínios, a onda vertiginosa de nacionalismos que está varrendo o continente africano.

E o pior ainda é que, da total subversão do sistema colonial a que estamos assistindo, não será difícil descortinar o desenvolvimento de poderes ocultos no sentido de um novo colonialismo a implantar em África, com a mira de se substituírem, política e economicamente, às nações do Ocidente, já então destituídas dos seus direitos de soberania.

Não deixou Portugal, desde o primeiro momento, de ver clara a situação, e, fiel a si próprio e às suas tradições, cônscio dos seus direitos e deveres que lhe impõe a acção civilizadora por ele desenvolvida durante séculos nos seus domínios de além-mar, verdadeiro prolongamento da Pátria e como tal integrados na unidade nacional, reagiu com firmeza contra toda a ideia de alienação dos seus territórios, disposto a enfrentar, com honra e corajosamente, os acontecimentos, quaisquer que eles fossem.

Daí os ataques de que passámos a ser alvo na Organização das Nações Unidas, que defrontámos com decisão e vigor - seguros da verdade e da força das nossas razões -, e, em ligação com eles, os actos traiçoeiros de terrorismo praticado em Angola, dimanados e dirigidos do exterior, em que de começo perderam a vida, a par de valorosos elementos da força armada, em defesa da ordem, cerca de duas centenas de brancos - homens, mulheres e crianças 
- e grande número de indígenas fiéis, traiçoeiramente atacados nas suas fazendas agrícolas e assassinados com requintes de malvadez e crueldade.

Pesadas baixas estão sendo infligidas aos bandoleiros, nas operações de repressão levadas a cabo pelas forças armadas que actuam na região.

Este é o balanço dos graves acontecimentos que, a coberto da campanha internacionalmente movida contra Portugal e com a finalidade de lhe dar corpo e avolumar, vieram enlutar a pacífica e laboriosa população de Angola.

Inclinando-nos em piedosa homenagem à memória de quantos perderam a vida em defesa da ordem e dos altos princípios orientadores da nossa acção civilizadora em terras de África, aqui deixamos exarado veemente protesto contra a campanha de que estamos sendo vítimas e a nossa indignada repulsa pela hedionda série de crimes e trágicas perturbações por que ela se traduz em Angola, ao mesmo tempo que patenteamos ao Governo, como símbolo da unidade espiritual de todos os portugueses, o nosso apoio e solidariedade nesta hora grave da vida nacional."17

\section{Política internacional}

Sintetizando, a preparação e publicação de Art Décoratif Tshokwe ocorre num contexto de contestação à política colonial portuguesa, no centro da qual a Diamang se verá envolvida. O trabalho no Dundo ocorre um ano após a Conferência de Bandung (em 1955) e a sua publicação coincide com o início da luta armada pela independência em Angola (em 1961). O patrocínio daquilo que eram consideradas "artes negras", seja por este meio, seja pelo desenvolvimento do próprio Museu do Dundo, não é, neste contexto político internacional, inocente. Através deles a Diamang apresenta-se publicamente, não tanto como empresa industrial, mas, junto de um público influente formado por elites interessadas em “arte negra” ou em “arte africana”, como patrono das artes. Já em meados dos anos 60, é também esta a opinião de René Pélissier:

"Museu do Dundo (concessão da Diamang, Dundo, Lunda)

As opiniões dos convidados da Diamang sobre a sua política social são tão variadas quanto as suas origens. Uma coisa deve, porém, ser dita a seu favor. Nada, absolutamente nada, obrigava esta empresa eminentemente capitalista a lançar-se na 'cultura', e os seus accionistas teriam podido continuar a receber os seus dividendos, sem ter mais do que a sua boa consciência a embalá-los nas noites deste gigantesco patrocínio diamantífero na fronteira do Cassai. A Diamang conseguiu montar de raiz o melhor museu de arte africana do mundo português. O prestígio que dele recolhe transcende as suas actividades comerciais. Num edifício imenso e austero, os 
organizadores juntaram todos os elementos da vida material e espiritual do povo para cujas terras vieram trabalhar, mas quiseram ao mesmo tempo fazer um museu vivo, subvencionando uma arte que iria morrer sob as escavações. Dá um certo gozo saber que os 'diamantistas' de Londres e Amsterdão, contribuem do seu bolso para a conservação da plástica negro-africana. Pouco visitado por europeus, uma vez que para entrar na concessão é indispensável um convite, o museu está essencialmente destinado aos Quiocos de quem conserva as tradições. É bom saber que estas 12.000 peças foram, em muitos casos, legadas por músicos, artistas, chefes ou simples camponeses" (Pélissier 1979 [1967]: 24-25).

\section{O museu e os seus duplos}

A eclosão da guerra colonial trará como alteração mais significativa ao Museu do Dundo o aumento de "visitantes brancos", na sua esmagadora maioria militares. Mas os receios manifestos por Ernesto de Vilhena na sua carta a Olbrechts (cf. supra) relativamente à exposição dos objetos não virão a ter fundamento, mantendo-se a prática expositiva estabelecida, respondendo a "uma preferência marcada pelo número" que "corresponde ao gosto dos indígenas". Acontece, porém, que não é aos "indígenas" que é, agora, útil mostrar o museu, mas, ao contrário, fora da Lunda, onde será eventualmente possível suscitar alianças para a cultura quioca, o Museu, a Diamang e Portugal, não necessariamente por esta ordem. A política de divulgação exterior do trabalho do museu iniciada nos anos 50 é, assim, reforçada na década seguinte mediante quatro tipos de ações: a exposição de exemplares escolhidos de arte negra, afinada com a estadia de J.O. Oliveira e M.-L. Bastin; a produção de números das Publicações Culturais de caráter propagandístico; a abertura perante alguma imprensa estrangeira; e, finalmente, a produção de um filme destinado ao circuito comercial. Mantém-se, a par destas iniciativas, a receção a cientistas e seus colaboradores, ligeiramente incrementada ao nível da colónia devido à criação do Instituto de Investigação Científica de Angola, em 1956, bem como à colaboração com as instituições da metrópole política neste domínio, onde se registam, também, alterações significativas.

\section{As exposições}

As primeiras exposições de representação do Museu do Dundo são realizadas em Portugal e no Brasil. Na continuidade da integração de secções culturais noutro tipo de certames dedicados à mostra do trabalho industrial e de colonização, trata-se de exposições fotográficas. A primeira é organizada sob a égide da "ocupação científica do Ultramar Português", sendo realizada em junho de 1951, a convite do Secretariado Nacional de Informação, Cultura Popular e Turismo, no Palácio Foz, em Lisboa. Tem por título "Missão Folclórica do Prof. Arthur Santos à Lunda e Alto Zambeze: Alguns Documentos Fotográficos da 
Missão" (cf. Museu do Dundo 1951), consistindo na primeira iniciativa na metrópole onde são dadas a audição pública as gravações de "música quioca" selecionada pelo colaborador do Museu. Notar-se-á que esta exposição coincide com a efetivação da visita de G. Freyre a Portugal, e, portanto, com um momento de reorganização da atitude política e pública em relação à questão colonial. No ano seguinte tem lugar no Rio de Janeiro uma montagem desta exposição, com o título "Exposição de Fotografias Relativas ao Folclore Musical Angolano (Região do Alto Zambeze)" (cf. Museu do Dundo 1952), onde novamente se procede à audição pública de música gravada pela Missão de Folclore Musical.

Após a passagem de J.O. Oliveira pelo Dundo e a seleção das melhores peças por parte de M.-L. Bastin, tem lugar a primeira exposição de objetos da coleção do museu, nos meses de outubro e novembro de 1958, fora de Angola. Trata-se da exposição "L'Art des Batshioko: Peuple de l'Angola”, realizada na Casa de Portugal, em Paris, sob "orientação etnográfica de J. O. Oliveira e realização artística de Paulo Ferreira”, segundo o catálogo respetivo (Museu do Dundo 1958). Nele se tece, a título introdutório, o louvor à sagacidade da Companhia pela elaboração do museu, e do seu papel no projeto colonial, no que parece ser uma adaptação do texto da Breve Notícia sobre o Museu do Dundo distribuído aos visitantes na Lunda (Diamang s. d.). O sucesso da exposição determina a sua itinerância para Marselha, onde será montada no Museu Cantini, de março a abril de 1959. Com este catálogo de Paris se inicia uma das alternativas impressas nos catálogos das exposições seguintes, uma listagem da opinião de "visitantes ilustres" sobre o Museu do Dundo. ${ }^{18}$ Alternativamente, estes catálogos incluem fotografias de algumas peças, como acontece no ano seguinte, quando em agosto de 1959 é realizada a exposição "A Arte de um Povo de Angola", na cidade de Salvador, na Baía, por ocasião do IV Colóquio Internacional de Estudos Luso-Brasileiros (cf. Museu do Dundo 1959).

Sem grandes variações no texto e nos objetos valorizados pelo seu crescente curriculum expositivo - materializando o conceito de arte tshokwe junto da opinião pública internacional -, realiza-se em 1961, em Colónia, no Joest Museum für Völkerkunde, a exposição "Die Kunst der Vatchivokwe, eines Volksstammes in Angola" (cf. Museu do Dundo 1961). Prevista para 15 dias, a exposição de Colónia manteve-se aberta por dois meses, acolhendo cerca de 15 mil visitantes.

18 No catálogo de Paris (Museu do Dundo 1958), iniciam-se com a do Abade Breuil, prosseguindo com a de Franz Olbrechts, Hugh Tracey (diretor da International Library of African Music), Prof. Oliver Davies (Achimota College, Ghana), Léon Kochnitzky, autor de Negro Art in Belgian Congo (Nova Iorque, 1952), e Léon Bourdon (Universidade de Paris e diretor do Instituto de Estudos Portugueses e Brasileiros na Sorbonne). 
No ano seguinte, 1962, Madrid e Barcelona acolhem a Exposición de Arte Negro del Pueblo Quioco de Lunda-Angola, no primeiro caso na Sala de Exposiciones de la Dirección General de Bellas Artes, Palacio de Bibliotecas y Museos (cf. Museu do Dundo 1962a), no segundo na Sala de Exposiciones de la Biblioteca Central (cf. Museu do Dundo 1962b). O texto do catálogo de Barcelona - pouco diferindo do de Madrid e baseado no de Paris -, assinado por Alvaro Montenegro, recorda que apesar de a exposição de arte negra do Museu do Dundo ter sido apresentada inicialmente em Paris, cabe à Espanha a primazia na apreciação das coleções, por meio das conferências realizadas no Ateneo de Madrid por J. O. Oliveira em 1955 e, no ano seguinte, na Universidade Internacional de Verão em Santander, por ocasião da publicação do seu livro, também em castelhano, El Arte Negro... (Oliveira 1956). Mais se explica que fora na sua qualidade de colaborador dos Serviços Culturais da Diamang que o escritor organizara as quatro mostras anteriores (Paris, Marselha, Baía e Colónia), bem como as duas em Espanha. Para além da referência aos testemunhos transcritos no catálogo de Paris, o autor reporta-se às apreciações positivas de outros "visitantes ilustres" do Museu, ${ }^{19}$ para concluir com Marie-Louise Bastin, "colaboradora do Centre National d'Ethnologie des Peuples d'Outre Mer, Tervuren (Bélgica), que graças ao Museu do Dundo pôde realizar a sua obra exaustiva Art Décoratif Tshokwe" (cf. Museu do Dundo 1962b: s/p).

Quinze fotografias de peças expostas, todas elas "antigas" de acordo com as legendas, acompanham o texto. Também o catálogo de Viena - onde a exposição “Tshokwe: Kunst eines Afrikanischen Stammes in Angola” é aberta ao público entre janeiro e março de 1965, no respetivo Museum für Völkerkunde sublinha a responsabilidade do "escritor, africanista e crítico de arte negra" (Museu do Dundo 1965: 10) na organização da exposição, que conta 71 objetos, 12 reproduções de pinturas murais e 30 fotografias. Hermann Baumann é citado no preâmbulo do catálogo, num extrato do seu artigo "Arte", publicado na Enciclopedia Universale dell'Arte, em que a Diamang é louvada pelo desenvolvimento do Museu de Arte Tshokwe que mantém vivo o interesse dos seus executantes pela sua arte, salvando-a da europeização (cf. Baumann, cit. em Museu do Dundo 1965: 3). As fotografias do catálogo, feitas em Lisboa, são assinadas por Mário Novais.

O conjunto de exposições termina - tal como se iniciara - na metrópole, desta vez na cidade do Porto, em colaboração com a respetiva Câmara Municipal e com o Ateneu Comercial da cidade. A exposição decorre durante o mês de julho de 1966, sob a designação "A Arte de um Povo de Angola: Quiocos da

19 Designadamente J. Desmond Clark, (Rhodes-Livingston Museum, Rodésia do Norte), Hermann Baumann, "um dos mais notáveis africanistas de todos os tempos", Michel Déon, escritor francês e Julien Vanhove (Universidade de Liège) (cf. Museu do Dundo 1962b). 
Lunda". Tal como as anteriores, é bem-sucedida, tendo-se, no entanto, optado por uma diferente estratégia quanto às peças escolhidas, uma vez que

“poucas são as antigas que intervêm na presente exposição. De facto, entendem os dirigentes da 'Diamang' não deverem elas ser sujeitas aos riscos inerentes às grandes deslocações, muito acrescidos, sem dúvida, pela própria natureza dos materiais em que são confeccionados. Daí que, para uma melhor elucidação da Arte quioca, se tivesse, nesta exposição, lançado mão do método de reprodução fotográfica das peças mais significativas ou da apresentação de objectos modernos, executados pelos artistas privativos do Museu do Dundo dentro dos melhores cânones tradicionais" (Museu do Dundo 1966: 11-12).

Segue-se, a esta explicação, uma secção dedicada às "Opiniões sobre o Museu do Dundo", e uma série de oito fotografias de objetos.

O conjunto de exposições denota uma viragem - após a passagem de J.O. Oliveira e M.-L. Bastin pelo Dundo - da divulgação inicial do trabalho científico para a divulgação do trabalho sobre a "arte negra". As exposições têm por público-alvo os cultores das belas-artes e é por meio dessa relação com as elites culturais que se faz a associação entre a arte quioca, a colonização portuguesa, o Museu do Dundo e a Companhia. Posteriormente, esta mesma estratégia será posta em marcha no território de Angola, quando, em 1973, a Companhia decide transferir cerca de três mil peças escolhidas para a sua Casa de Representação, em Luanda, numa súmula significativa do que poderia ser visto no Dundo. Juntamente com as coleções etnográficas do Museu de Luanda (História Natural), são estas peças que constituem o "núcleo duro" do atual Museu Nacional de Antropologia de Luanda, sendo expostas como peças de valor etnográfico.

\section{"ARTES PRIMEIRAS" E O "PROJETO TCHOKWÉ"}

A reemergência do interesse público de Angola pela cultura material cokwe como arte parece ser relativamente recente, e é na capital, por via das artes contemporâneas, que a "arte Tshokwé" é colocada no centro do debate sobre a nacionalidade angolana. Neste debate entroncam fatores históricos mais amplos, comuns na ocupação colonial de África. Recorde-se, a este propósito, que o conhecimento das populações sob dominação colonial pelas diferentes metrópoles europeias baseou-se, em larga medida - e com variações significativas caso a caso - na apropriação, recolha, classificação e ordenação da cultura material dos grupos indígenas (no sentido etimológico do termo), tendo a hierarquização das coleções constituído um dos elementos de hierarquização interna dos grupos na perspetiva colonial (cf. Ravenhill 1996). Um dos 
critérios centrais de diferenciação (entre objetos e, a partir destes, entre os seus autores) foi a separação entre arte e artefacto: entre o domínio de objetos excecionais e transcendentes a um valor utilitário, e o domínio dos objetos de uso comum; entre agentes (os seus autores) capazes de juízo estético e agentes atavicamente reféns da solução técnica imediata e perecível.

O caso angolano tem características comuns com outros processos de imaginação de nações independentes engendrados após a situação colonial em África e que incorporaram as coleções museológicas produzidas no período colonial sob essa nova intenção. No quadro da ordem de relações emergente, os objetos e as classificações até então existentes assumiram novas intencionalidades de acordo com programas nacionais. Este processo contemporâneo é relevante para a compreensão da classificação como arte de parte da cultura material recolhida na situação colonial, sendo, simultaneamente, relevante para a compreensão do entendimento, nesse contexto, do que seja o campo da arte nos projetos nacionais em formação.

Para o caso em análise é possível identificar três ordens de questões. A questão central é a questão da arte e ela é central a dois níveis: por um lado, porque o termo, aplicado a objetos de coleções organizadas no período colonial como "etnográficas", serviu como forma de habilitação à participação num mercado de valores universais (implícito na noção de arte) de um conjunto de objetos antes relevantes apenas como exemplos de formas culturais locais (e portanto substituíveis e intermutáveis entre si enquanto espécimes). Por outro lado, porque após a situação colonial, os exemplares "artísticos" - referenciados como pré-coloniais - foram instituídos como as formas "mais verdadeiras" das culturas, agora, nacionais.

Uma segunda questão decorre da instabilidade do próprio campo da arte contemporânea, que se tem vindo a definir como a-nacional - e portanto como sendo ou válido em qualquer contexto ou como sendo não-arte - ao mesmo tempo que tem deslocado o seu campo de identificação do produto (a obra de arte), para o processo de trabalho e o conceito que o sustenta (cf. Belting 2006 [1995]). Esta segunda questão não é dissociável da primeira, na medida em que os processos de imaginação das nações após a situação colonial preconizam a sua identificação em paridade com "o resto do mundo", enunciando fraturas repercutidas entre o campo das artes e o da política. Ou seja, tanto as artes como os modelos de nação emergentes se instituem na refração da doxa, convocando posições alternativas a narrativas dominantes que carecem, elas próprias, de modelos explicativos ou interpretativos capazes de lidar com as peculiaridades do momento presente.

Finalmente, a relação entre os dois elementos anteriormente enunciados, a criação artística e a contemporaneidade, permite recentrar sob a questão cultural quer a questão colonial quer a questão nacional e admitir a possibilidade de que se possam registar recorrências entre os campos do político e do cultural. 
A hipótese de trabalho admite, assim, que o fecho formal da situação colonial não implica, necessariamente, o termo de relações coloniais, quer no campo político, quer no campo cultural. Parece ser um movimento com este tipo de complexidade que está em causa no Projeto Lunda-Tchokwé da 1. ${ }^{a}$ Trienal de Luanda (2006-2007), que coloca as coleções do Museu do Dundo no centro do debate.

\section{A Trienal de Luanda}

Enquadrado no ambicioso programa da 1. ${ }^{a}$ Trienal de Luanda (dezembro de 2006 a março de 2007), o Projeto Lunda-Tchokwé recorre à proclamação contemporânea da tradição para fundar uma proposta de modernidade. Não há, nisto, nada de estranho, na medida em que esta "Trienal de Arte Contemporânea" se constitui numa manifestação efémera de uma política cultural de identificação das especificidades nacionais que, no que concerne a cultura material, tem vindo a ser implementada desde a independência de Angola em 1975, com a fundação da Rede Nacional de Museus (cf. Porto 2001). O que é específico da Trienal, à semelhança, de resto, com outras mostras de arte contemporânea e, em particular, as que seguem o modelo do festival efémero, ${ }^{20}$ é uma colocação cosmopolita do país anfitrião em função das obras e artistas selecionados sob o propósito de identificar as tendências de trabalho futuro. Esta colocação, no entanto, e em função da sua localização geopolítica - África austral -, não se faz sem consequências para a própria noção de arte em exposição, que é suscetível de explicitar características contemporâneas do campo da arte. É necessário tê-las em consideração antes de uma análise mais detalhada do Projeto Lunda-Tchokwé, e elas podem ser agrupadas em três níveis.

Um primeiro nível é institucional, enunciando a progressiva subalternidade da instituição museológica na definição do campo da arte. Trata-se de um percurso historicamente recente que tem deslocado do Estado e dos museus nacionais - em prol de agentes privados associados a redes de galerias a autoridade na definição do cânone. Este deslocamento institucional não é, em segundo lugar, alheio a transformações nas práticas artísticas na segunda metade do século XX, que assiste à progressiva erosão de uma noção de arte centrada na obra e à consolidação de uma noção de arte centrada no conceito, nos processos de criação e no discurso em torno de ambos. Diversamente de outros casos de nações oriundas de relações coloniais, Angola não inscreveu no seu projeto nacional a constituição de um museu de arte contemporânea. No momento presente, tal possibilidade seria, em parte, anacrónica, na medida em que os propósitos de constituição de museus nacionais de arte

20 Vejam-se a Bienal de Veneza (desde 1895) e a Ducumenta de Kassel (1955), na Europa, a Bienal de Arte Contemporânea Banto, em Libreville, no Gabão (1985), a Dak'Art: Bienal de Arte Africana Contemporânea de Dakar (iniciada em 1992), ou a Bienal de Joanesburgo (iniciada em 1994-95). 
- designadamente a sua afirmação de um projeto de Estado assente na modernidade (cf. Duncan 1991) - foram, entretanto, transferidos para manifestações efémeras, como o são as bienais ou, no caso, a Trienal. Parte deste processo de reformulação das artes contemporâneas implica a porosidade relativa de posições, antes estruturais, dos diferentes agentes situados no mercado das artes. Entre elas, o desdobramento da atuação artística, por parte dos artistas plásticos, não apenas como criadores mas também como curadores de exposições (Cf. O’Neill 2007; Enwezor 2007). Este desdobramento mostra-se axial na 1. ${ }^{\text {a }}$ Trienal de Luanda, organizada pelo artista plástico e curador Fernando Alvim, e por Simon Njami, curador, crítico de arte e, desde 2001, comissário da Bienal de Fotografia de Bamako. ${ }^{21}$

Este processo de reformulação do campo das artes pode, ainda, ser entendido como expressão histórica da pós-modernidade, enunciando e ilustrando a rutura com um mundo de centros, hierarquias e princípios de ordem unívocos e reclamando, pelo contrário, a complexidade, ambiguidade, inter-relação e multirreferencialidade de princípios, normas e valores que gerem o mundo contemporâneo e se consubstanciam, parcialmente, no discurso dos chamados estudos pós-coloniais. A chamada "filosofia operacional" da Trienal é explícita quanto à sua colocação neste campo. Nas palavras de Simon Njami:

"É chegado atualmente o tempo de distinguir entre África e Africanos, entre identidade e nacionalidade, entre expressão e política. [...] Poderíamos, assim, avançar aqui que não se nasce africano, esta é uma condição que se adquire. [...] Adquirir a condição africana acaba por ser exprimir no mundo um ponto de vista" (2006: 1).

A articulação entre a declaração da identidade individual como escolha e a assunção de um lugar de locução (antes negadas pela situação colonial) abre o espaço de uma terceira característica deste processo de reformulação da noção e das práticas da arte contemporânea, que é o descentramento crítico, não apenas quanto à natureza do trabalho artístico (da obra para o conceito) e do papel fixo do artista (como criador conceptual, mais que artesão, passando a desenvolver a atuação artística enquanto curador), mas, sobretudo, em relação a um cânone que é denunciado como produto de relações de opressão e, por isso, rejeitado. Dito de outra forma: na perspetiva dos curadores da Trienal, o problema com a categoria de "arte africana" - e o desajuste desta categoria no mercado contemporâneo - é o adjetivo nela contido. Os artistas africanos não

21 Acrescente-se - sem que esta questão seja objeto do presente texto - que as exposições da Trienal foram quase exclusivamente baseadas na coleção privada do empresário congolês Sindika Dokolo, coleção essa anteriormente organizada por Fernando Alvim para o colecionador alemão Hans Bogatzke, a quem o empresário congolês a terá comprado (cf. Okeke-Agulu 2007). 
precisam de abdicar da uma identidade que foram tornando africana para produzir arte tout court, desprovida, portanto, da qualificação, neste caso depreciativa e subalternizante, como "africana" ${ }^{22}$ Liberto deste espartilho - prossegue Njami -, o artista africano entrega-se "ao mundo e à magia de se descobrir como nunca antes se vira" (2006: 2) e, ao fazê-lo, envolve-se na criação de arte. ${ }^{23}$

É neste campo fragmentário das artes contemporâneas, enunciado em tom afirmativo a partir da Angola posterior à situação colonial, que é necessário contextualizar o Projeto Lunda-Tchokwé, já que, na sua "filosofia estrutural", os curadores assumem que a essência da Angola independente é uma combinação crítica de passado, presente e futuro.

\section{O Projeto Lunda-Tchokwé}

O subtítulo do projeto é um programa tripartido em três ações: resgate, absorção e visibilidade. O projeto consiste na

"Edição de serigrafia electrónica sobre tela, das pinturas Lunda-Tchokwé a partir das ilustrações de José Redinha. A Trienal de Luanda propõe analisar o trabalho de investigação sobre a estética pictórica e filosófica dos povos da região Lunda, Noroeste de Angola, conforme referenciado em obra editada por José Redinha, em 1953. Esta retoma sobre uma obra previamente editada, reflecte o espírito do movimento cultural do qual a Trienal de Luanda se intui.

$[\ldots]$

É urgente uma releitura do mesmo fenómeno numa perspectiva contemporânea e sem preconceitos.

Como proposta de melhoria sobre este espólio, a Trienal apresenta este projecto ao grande público já com as referidas alterações e motivos, permitindo a cada um de nós descodificar esta proposta estética e a sua contemporaneidade da expressão artística no início do século XX em Angola.

Imprimimos 99 serigrafias de imagens representativas dos primeiros registos da pintura Lunda-Tchokwé produzidas sobre tela, na expectativa de que a obra intervenha e circule como referência histórica do imaginário Lunda. As obras terão a dimensão equivalente a três metros quadrados de superfície, respeitando as suas dimensões originais.

22 Ocolecionador declara ter pretendido estabelecer não uma coleção de "arte africana contemporânea", mas uma coleção "africana de arte contemporânea". Ver < http://www.fondation-sindikadokolo. com/wp-content/uploads/2008/02/manifesto_dokolo_pt.pdf > (p. 3, última consulta em janeiro de 2015).

23 Do mesmo modo que o artista europeu ou norte-americano se envolve na produção de arte tout court, sem que a arte que produz careça da qualificação de "europeia" ou "norte-americana", respetivamente. 
Por este projecto ser pioneiro na proposta de um reajuste cultural no registo das artes plásticas angolanas e pelo inegável valor do espólio, a Trienal de Luanda irá consagrar esta edição ao Estado Angolano, propondo integrá-lo no Tesouro Nacional como Colecção Oficial de Estado. O resultado da criação desta colecção será a constituição de um primeiro espólio representativo das Artes Primeiras de Angola. Acreditamos que esta interacção não só realça a importância da cultura e das artes plásticas, permitindo sinergias positivas à vida da nação, como reajusta a proximidade intrínseca que deve prevalecer entre o mundo cultural e os espaços políticos e económicos em Angola." 24

Formalmente, o projeto consistiu na impressão de outdoors de três metros quadrados de superfície destinados a ser distribuídos pelo espaço urbano da cidade, no que pode ser considerado um projeto de arte pública dirigido à população de Luanda. Ao fazê-lo, o curador da Trienal pretendeu "resgatar" - usando a sua expressão - a pintura lunda-tchokwé do "gueto" etnográfico, dignificando esta forma de expressão plástica como arte do século XX angolano. O resgate da pintura lunda-tchokwé assume, assim, uma dimensão fundadora da modernidade angolana, visível nas suas artes plásticas e atuando, ao mesmo tempo, como antecessor do início do século XX, da Trienal em curso. Por outras palavras, a Angola pré-colonial (a "ocupação efetiva" das Lundas ocorreu nos anos 20), como demonstram as pinturas lunda-tchokwé, era uma nação interessada nas artes plásticas, sendo, portanto, natural - no âmbito da Trienal - a recuperação desse passado, resgatado, agora, como "artes primeiras" (supõe-se, no sentido de artes plásticas por oposição a "artes tribais"). ${ }^{25}$ Não é de excluir que a seleção das paredes pintadas da Lunda, como objeto de resgate, provenha da confessada influência que estas pinturas tiveram na obra do pintor Joaquim Rodrigo, que introduziu a expressão plástica e conceptual cokwe na pintura contemporânea no decurso dos anos 60 (cf. Miranda 2006), conferindo-lhes uma acrescida legitimação que vem a torná-las adequadas ao público-alvo da Trienal: a elite de Luanda e suas conexões cosmopolitas que assim se estabelecem como guardiães e intérpretes da identidade nacional. Com o projeto, a Trienal produz património histórico no domínio das artes plásticas, "primeiras", enquanto propriedade do Estado.

24 < http://www.trienal-de-luanda.net> (consultado em 15 de abril de 2008, já não disponível).

25 "Artes primeiras" é a designação adotada pelo atual Museu do Quai Branly (inaugurado em Paris em 2006) numa solução de compromisso para requalificar coleções constituídas por objetos recolhidos como etnográficos provenientes de diferentes museus parisienses (cf. Dias 2003). O uso desta expressão, neste contexto, não é, portanto, neutro. 


\section{Paredes Pintadas da Lunda, de José Redinha (1953)}

Foi enquanto conservador do Museu do Dundo que José Redinha efetuou a pesquisa sobre a pintura (então, e nesse contexto) "quioca", entre os anos de 1938 e 1944, sob modalidades investigativas de campanha (cf. supra; Cohn 1996: 5), essencialmente destinadas à recolha de objetos para o museu. Em 1938, a campanha percorreu a região do Sombo, onde a escultura - principal objeto de recolha das campanhas - não era uma atividade muito praticada:

"Em contrapartida notou-se ali, entre o indígena, uma interessante tendência para a pintura - para a decoração das palhotas com frisos, a cores, representando danças, combates, cerimónias da vida oculta do gentio; retratos de europeus, artefactos, animais e figuras convencionais do sol e das estrelas.

Destas pinturas murais foram extraídos apontamentos que se destinam a um álbum colorido, já bastante adiantado, e que ficará sendo uma das melhores curiosidades etnográficas do nosso Museu" ${ }^{26}$

Na campanha de 1940,

“[...] foram os documentários gráficos, sobretudo, o fim principal desta campanha, tendo sido executados 177 desenhos de pinturas indígenas, 96 de habitações, 150 de tatuagens e 39 diversos, além de outros subsídios de interesse para a colecção." ${ }^{27}$

As recolhas prosseguem e, em 1943, os documentários gráficos são ampliados:

"De 19 de Julho a 20 de Agosto do ano findo realizou-se uma campanha para recolha de pinturas murais dos indígenas, assunto este que fora recomendado pelo Senhor Administrador-Delegado [o Comandante Ernesto de Vilhena, aquando da sua missão à Lunda em 1942]. Assim, o número dos apontamentos já existentes, foi aumentado com mais de 40 páginas, onde se encontram dezenas de motivos, coloridos, dessas pinturas." ${ }^{28}$

Em 1947, o conservador relata encontrar-se pronto "[...] um volume acerca das paredes pintadas da Lunda". ${ }^{29} \mathrm{O}$ projeto fora, entretanto, validado pelo administrador-delegado da Companhia e viria a ser publicado em 1953. Nele

26 Arquivo documental da Diamang, Museu do Dundo, Relatórios Anuais, 1938, p. 4.

27 Arquivo documental da Diamang, Museu do Dundo, Relatórios Anuais, 1940, p. 6.

28 Arquivo documental da Diamang, Museu do Dundo, Relatórios Anuais, 1943, p. 3.

29 Arquivo documental da Diamang, Museu do Dundo, Relatórios Anuais, 1947, p. 7. 
se qualificam as pinturas murais como "arte de amadores", sazonal - da "época seca ou do cacimbo" -, efémera - "desaparecem irremediavelmente lavadas pelas primeiras chuvas" -, na sua maioria com valor de crónica da "vida diária, reflectindo, como um jornal ilustrado, incidentes notáveis, modas, preocupações e alegrias" (Redinha 1953b: 9-10). Na análise formal e estilística destas pinturas, Redinha diferencia entre a pintura decorativa e a pintura figurativa, passando em análise os recursos formais, convencionais e cromáticos dominantes, bem como as técnicas pictóricas usadas para "representação do volume", domínio no qual este "povo de escultores" "não vai além de tantos outros povos primitivos". Outro tanto dirá sobre a profundidade e a perspetiva, concluindo que esta "pobreza de interpretação plástica [...] é de regra entre os povos primitivos" (Redinha 1953b: 12). Mais adiante na introdução, lidando com a questão das origens desta arte, Redinha escreve:

"Na sua forma actual de pintura de parede argilosa, a pintura mural parece ser relativamente recente entre os povos da Lunda. Dando crédito à tradição dos naturais, a introdução ou vulgarização das paredes de argila nas habitações foi devida ao exemplo da construção europeia. Não temos dados seguros para confirmar esta versão. Todavia, temo-la escutado muitas vezes, e acontece encontrar-se grande número de indígenas que não gostam das casas com paredes de argila, nem consideram o seu uso conveniente 'Entre paredes de terra, só os mortos', dizem. Alguns sobas não consentem mesmo que se construam paredes de argila [...] por motivos de superstição" (1953b: 13).

A metáfora do processo colonial em curso como aprisionamento - ou mesmo genocídio - não poderia ser mais explícita: são as habitações de inspiração europeia - próprias para mortos na "superstição" indígena - que se prestam a esta arte. Dada a colocação de Redinha, aquando das campanhas, no processo colonial em curso, as pinturas são tomadas por "curiosidade" e constituídas, por processos canónicos, em objetos de etnografia (cf. Kirshenblatt-Gimblett 1991): a excisão do seu contexto por mediação documental e sua deslocação, a redução de escala e transubstanciação noutro suporte, todo o processo de classificação, ordenação e comparação interna transformam estas pinturas numa "das melhores curiosidades etnográficas do nosso Museu". ${ }^{30}$ Dado este posicionamento, os propósitos da recolha e a configuração colonial em que é efetuada, a possibilidade especulativa de qualificar esta como uma pintura de resistência, de quem, sendo "enterrado vivo" entre paredes de argila, expressa uma vitalidade anticolonial, não é suscetível de se colocar ao conservador do museu. Cinquenta anos depois, contudo, traduzindo a pintura em - agora - 
“arte primeira”, o processo de resgate para o campo das artes parece, em tudo, ser idêntico ao da sua canonização colonial na etnografia.

Com efeito, o Projeto Lunda-Tchokwé - que, como se viu acima, configura um projeto urbano de arte pública - alicerça-se, novamente, na transformação do objeto por deslocação (para exposição em outdoors), que implica uma mudança de suporte para tela (eletronicamente serigrafada), e uma alteração significativa de escala (da página do livro para o outdoor), bem como processos de classificação, ordenação e comparação interna com base num valor estético. Em segundo lugar, ao dedicar a nova edição ao Estado angolano, os curadores da Trienal obliteram a sedimentação do Museu do Dundo como museu de comunidade das populações Lunda-Cokwe (cf. supra), deslocando para o centro político a capacidade - sob debate, do ponto de vista cultural - de representar o Leste. Em terceiro lugar, não será excessivo recordar que o caráter excecional do Museu do Dundo no árido panorama de museologia colonial do Império Português terá contribuído para a transição das categorias coloniais de autenticação desses objetos como pré-coloniais para o período posterior à situação colonial. Collier, a este propósito, sublinha que, no processo de redescoberta das paredes pintadas da Lunda como artes primeiras, a assinatura de Redinha é apagada nas versões digitalizadas pela Trienal, e argumenta que a alteração do suporte (do livro para o outdoor ou para ao universo digital) efetua, de facto, uma mudança na própria obra (cf. Collier 2008, 2010). Finalmente, e segundo o próprio Redinha, a pintura resgatada pela Trienal como "arte primeira" é, quando muito, uma pintura de resistência colonial, que existiu na sequência de um processo de ocupação que forçou as populações a habitar casas "próprias para mortos". O "resgate" que o Projeto Lunda-Tchokwé se propõe efetuar acaba, eventualmente, por substanciar um exercício de colonialismo interno, nacionalizando o que é específico do Leste, e como tal reivindicado pelas suas autoridades tradicionais, e purgando essas artes da configuração política que as engendrou, remetendo-as para um passado que nem o próprio Redinha supôs.

Cabe notar, neste processo, que esta deslocação do "etnográfico" para o campo das artes redobra um deslocamento da periferia - de Leste - para a capital. Aparentemente, o projeto da Trienal passou relativamente despercebido no Dundo ${ }^{31}$ e, na capital, não terá sido propriamente pacífico, originando uma polémica registada, entre outros, pelo Jornal de Angola. Jorge Gumbe, por exemplo, contesta a macrocefalia da Trienal em geral e, muito particularmente, a pertinência do projeto tchokwé. Nas suas palavras:

"A Trienal estando localizada em Luanda, previa inserir-se num contexto nacional trabalhando com artistas de todo o país e mostrando durante a 
Trienal tudo o que se faz em termos artísticos nas províncias. Dizia-se que a produção artística das províncias estava a ser alvo de uma pesquisa e recolha cujo resultado seria apresentado durante este evento. Onde está? Afinal qual foi o resultado da investigação pelo país?

Pergunto se no Uíge, Lunda Norte e Sul, Saurimo, Namibe, Benguela e Lobito, Ndalatando, Sumbe, Gabela, Malanje, Menongue, Ondjiva e tantas outras cidades e comunidades do país, será que não existem artes e artistas? Qual o lugar dos artistas angolanos na diáspora? Onde estão? Existem especialistas angolanos que há longos anos têm seriamente desenvolvido este trabalho" (Gumbe 2007).

E em relação ao Projeto Lunda-Tchokwé, afirma:

"A Trienal de Luanda fez sair uma edição exclusiva de aproximadamente cem (100) serigrafias sobre tela, que deveria ser entregue ao governo angolano, com o objectivo de ser catalogada como património de Estado. No seu entender seria assim criada a primeira colecção de Estado em Angola. Eu pergunto, qual património? As cópias de cópias? Para quê que o governo angolano quereria ficar com cópias de cópias, que do meu ponto de vista e convencionalmente estabelecido, porque se aprende numa escola de arte, não tem nenhum valor como obra de arte, quando existem os originais. Haja mais respeito às instituições oficiais do país." (Gumbe 2007)

Não é de supor, nesta intervenção, que o que está em causa seja, sequer, que os registos elaborados por Redinha possam ser tomados como pinturas cokwe. Os originais a que Gumbe se reporta são originais de Redinha válidos, precisamente, enquanto registos permanentes de pinturas efémeras, essas sim, de origem cokwe. No seu tom geral, a manifestação de indignação de Gumbe relativamente à primeira Trienal parece ser concordante com uma apreciação feita por António Ole, ${ }^{32}$ e também, por Adriano Mixinge:

"Por trás do discurso aparentemente bem-intencionado, franco, conciliador, sem preconceitos dos organizadores, temo que na verdade haja um outro eticamente escuro, pouco dado ao diálogo, dado a manipulação de políticos e empresários, capaz do maior egoísmo e de estruturar, em nome da Nação, uma Trienal de Arte para inglês ver, sem se importar realmente pelo desenvolvimento das artes plásticas angolanas e ignorando completamente aqueles que sempre aqui estiveram e continuam a trabalhar, com muitas dificuldades" (Mixinge 2005). 


\section{Artes e nação}

Independentemente do calor próprio das intervenções do momento, terá acontecido que, de facto, o "inglês" viu. E um momento subsequente parece ter afirmado o incontestável sucesso da Trienal, que pode aferir-se pela posterior seleção, por concurso, desta mesma coleção (de Sindika Dokolo) para representar África na Bienal de Veneza de 2007.33 O efeito conjugado destes dois processos, em termos internacionais, consistiu no estabelecimento de Angola como um ator axial no mercado das artes contemporâneas em África, posição que se projeta prosseguir por via, entre outros, da consolidação da Trienal como centro das artes contemporâneas na África Austral. Nesse processo, a Trienal estabeleceu uma componente de reivindicação histórica nacional, que recorre ao património museológico e, partindo do centro político e atuada por elites cosmopolitas, reconfigura o significado contemporâneo dos objetos do passado de acordo com as suas próprias agendas. O processo contemporâneo de "resgate" de um património nacional parece, assim, desenvolver-se num paralelismo quase mimético com o processo colonial que instituiu - como elementos pré-coloniais prístinos - o mesmo tipo de artefactos, enunciando a sua classificação como "arte" - hoje como no "tempo do colono" - como uma forma de empoderamento, não tanto das populações que produziram e consumiram esses objetos, mas, sobretudo, daqueles que se posicionam como seus curadores, conservadores e locutores. No caso concreto, esta persistência do recurso à categoria de "arte" é, ainda, um atestado da sua eficácia política e, para os efeitos do argumento aqui apresentado, a confirmação de que a compreensão da questão das artes carece da elucidação de um contexto mais amplo, onde os fatores culturais se articulam com questões de natureza económica e política, a escalas nacionais e globais que se influenciam e interpenetram mutuamente. De um ponto de vista antropológico, é este aglomerado de processos de fabricação da nação que é colocado em evidência pela análise do campo das artes.

33 Originando uma das mais politizadas polémicas sobre os processos de seleção dos organizadores da Bienal, motivada, em grande parte, pelo facto de o colecionador ser genro do Presidente de Angola (cf. Davis 2007). 


\section{BIBLIOGRAFIA}

BASTIN, Marie-Louise, 1961, Art décoratif Tshokwe. Lisboa, Publicações Culturais do Museu do Dundo - Companhia de Diamantes de Angola, 2 vols. [edição em português: Arte Decorativa Cokwe, Coimbra, Museu Antropológico da Universidade de Coimbra, Secção de Antropologia do Museu de História Natural da Universidade de Coimbra e Museu do Dundo, 2010].

BASTIN, Marie-Louise, 1973, La sculpture Tshokwe: Essai iconographique et stylistique. Bruxelas, Université Libre de Bruxelles, tese de doutoramento.

BASTIN, Marie-Louise, 1982, La sculpture Tshokwe. Meudon, Alain et Françoise Chaffin.

Belting, Hans, 2006 [1995], O Fim da História da Arte: Uma Revisão Dez Anos Depois. São Paulo, Cosacnaify.

COHN, Bernard S., 1996, Colonialism and Its Forms of Knowledge: The British in India. Princeton, Princeton University Press.

COLLIER, Delinda, 2008, "The (dis)placement of national art in a transnational artworld: Trans/nationalism in Angola", African Arts, 41 (3): 10-12.

COLlIER, Delinda, 2010, Art in a State of Emergency: Figuring Angolan Nationalism, 1953-2007. Atlanta, GA, Emory University, tese de doutoramento em História de Arte.

DAVIS, Ben, 2007, "Reply to Storr", em Artnet Magazine, disponível em < http://www. artnet.com/magazineus/news/davis/davis7-17-07.asp > (acesso em 15/04/2008, última consulta em janeiro de 2015).

DiAmang, s.d., Breve Notícia sobre o Museu do Dundo. Lisboa, Companhia de Diamantes de Angola.

DIAS, Nélia, 2003, "Ethnographie, art et arts premiers: la question des désignations", Arquivos do Centro Cultural Calouste Gulbenkian, XLV: 3-13.

DUNCAN, Carol, 1991, "Art museums and the ritual of citizenship", em Ivan Karp e Steven Lavine (orgs.), Exhibiting Cultures: The Politics and Poetics of Museum Display. Washington, Smithsonian Institution Press, 88-101.

ENWEZOR, Okwi, 2007, “Curating beyond the canon: an interview by Paul O’Neill”, em Paul O’Neill (org.), Curating Subjects. Londres, Open Editions, 109-122.

FABIAN, Johannes, 1998, "Curios and curiosity: Notes on reading Torday and Frobenius", em Enid Schildkrout e Curtis A. Keim (orgs.), The Scramble for Art in Central Africa, Cambridge, Cambridge University Press, 79-107.

FONTINHA, Mário, e Acácio VIDEIRA, 1963, Subsídios para a História, Arqueologia e Etnografia dos Povos da Lunda: Cabaças Gravadas da Lunda. Lisboa, Companhia de Diamantes de Angola.

GUMBE, Jorge, 2007, “Trienal de Luanda: Indignação”, nota de imprensa, Jornal de Angola, 5 de janeiro.

KEIM, Curtis A., 1998, "Artes Africanae: the Western discovery of 'Art' in Northeastern Congo", em Enid Schildkrout e Curtis A. Keim (orgs.), The Scramble for Art in Central Africa, Cambridge, Cambridge University Press, 109-132.

KIRSHENBLATT-GIMBLETT, Barbara, 1991, "Objects of ethnography”, em Ivan Karp e Steven Lavine (orgs.), Exhibiting Cultures: The Politics and Poetics of Museum Display. Washington, Smithsonian Institution Press, 386-433.

LIMA, Mesquitela, 1967, Subsídios para a História, Arqueologia e Etnografia dos Povos da Lunda: Os Akixi (Mascarados) do Nordeste de Angola. Lisboa, Companhia de Diamantes de Angola. 
MACK, John, 1994, Emil Torday and the Arts of the Congo. Londres, British Museum.

MIRANDA, Carlos, 2006, O Índice Certo: Uma Abordagem Antropológica da Obra de Joaquim

Rodrigo. Braga, Universidade do Minho, tese de mestrado em Antropologia.

MIXINGE, Adriano, 2005, "Reflexão: As críticas e as razões do desconforto, Trienal de Arte de Luanda", Jornal de Angola, 12 de outubro.

MUSEu DO DUNDO, 1951, Missão Folclórica do Prof. Arthur Santos à Lunda e Alto Zambeze: Alguns Documentos Fotográficos da Missão, catálogo da exposição realizada no Secretariado Nacional de Informação, Cultura Popular e Turismo (Lisboa), junho.

MUSEU DO DUNDO, 1952, Exposição de Fotografias Relativas ao Folclore Musical Angolano (Região do Alto Zambeze), catálogo da exposição realizada no Rio de Janeiro. Lisboa, Bertrand.

MUSEU DO DUNDO, 1958, L'Art des Batshioko, peuple de l'Angola, catálogo da exposição realizada na Casa de Portugal, Paris (França), outubro-novembro.

MUSEU DO DUNDO, 1959, A Arte de Um Povo de Angola, catálogo da exposição realizada por ocasião do IV Colóquio Internacional de Estudos Luso-Brasileiros, Salvador da Baía (Brasil), agosto.

MUSEU DO DUNDO, 1961, Die Kunst der Vatchivokwe, eines Volksstammes in Angola, catálogo da exposição realizada no Rautenstrauch, Joest Museum für Völkerkunde, Colónia (Alemanha), setembro-outubro.

MUSEU DO DUNDO, 1962a, Exposición de Arte Negro (Del Dueblo Quioco, de Lunda - Angola), catálogo da exposição realizada na Sala de Exposiciones de la Dirección General de Bellas Artes, Palacio de Bibliotecas y Museos, Madrid (Espanha), outubro.

MUSEU DO DUNDO, 1962b, Exposición de Arte Negro (Del Pueblo Quioco, de Lunda - Angola), catálogo da exposição realizada na Sala de Exposiciones de la Biblioteca Central de Barcelona, patrocinada pela Dirección General de Bellas Artes, Barcelona (Espanha), novembro-dezembro.

MUSEU DO DUNDO, 1965, Tshokwe: Kunst eines Afrikanischen Stammes in Angola, catálogo da exposição realizada no Sonderusstellung Museum für Völkerkunde, Viena (Áustria), janeiro-março.

MUSEU DO DUNDO, 1966, A Arte de Um Povo de Angola: Quiocos da Lunda, catálogo da exposição realizada na Casa do Infante (Porto), julho.

NJAMI, Simon, 2006, "Contra a ilusão universalista", disponível em < http://www.fondation-sindikadokolo.com/wp-content/uploads/2008/03/contra-a-ilusao-universalista_ njami_pt.pdf > (última consulta em janeiro de 2015).

O'NEILL, Paul, 2007, “Introduction: Paul O’Neill interviewed by Anne Fletcher”, em Paul O’Neill, (org.), Curating Subjects. Londres, Open Editions, 11-19.

OKEKE-AGUlU, Chika, 2007, "Venice and contemporary African art", in African Arts, 40 (3): $1-5$.

OLIVEIRA, José Osório de, 1956, El Arte Negro como Expresión Humana y como Valor Cultural. Madrid, Indice.

PÉLISSIER, René, 1979 [1967], “Institutions africanistes portugaises”, em René Pélissier, Le naufrage des caravelles: Etudes sur la fin de l'Empire Portugais (1961-1975). Montamets, Editions Pélissier, 17-25.

PORTO, Nuno, 2001, "The arts of the Portuguese empire: The emergence of Cokwe Art in the province of Angola", em Anthony Shelton (org.), Collectors: Expressions of Self and Other, Contributions to Critical Museology and Material Culture. Horniman Museum and Gardens/Museu Antropológico da Universidade de Coimbra, 225-247. 
RAVENHILL, Philip L., 1996, “The passive object and the tribal paradigm: Colonial museography in French West Africa”, em Mary Jo Arnoldi, Christraud M. Geary e Kris L. Hardin (orgs.), African Material Culture. Bloomington e Indianapolis, Indiana University Press, 265-282.

REDINHA, José, 1953a, Subsídios para a História, Arqueologia e Etnografia dos Povos da Lunda: Campanha Etnográfica ao Tchiboco (Alto-Tchicapa), vol. I: Notas de Viagem. Lisboa, Companhia de Diamantes de Angola.

REDINHA, José, 1953b, Paredes Pintadas da Lunda. Lisboa, Publicações Culturais do Museu do Dundo - Companhia de Diamantes de Angola.

REDINHA, José, 1955, Subsídios para a História, Arqueologia e Etnografia dos Povos da Lunda: Campanha Etnográfica ao Tchiboco (Alto-Tchicapa), vol. II: Anotações e Documentação Gráfica. Lisboa, Companhia de Diamantes de Angola.

REDINHA, José, 1956, Subsídios para a História, Arqueologia e Etnografia dos Povos da Lunda: Máscaras de Madeira da Lunda e Alto Zambeze. Lisboa, Companhia de Diamantes de Angola. 